\title{
PENGARUH WORD OF MOUTH TERHADAP KEPUTUSAN PEMBELIAN TIKET MASKAPAI PENERBANGAN DOMESTIK DI DAVINA TOUR AND TRAVEL GORONTALO
}

\author{
Rini Andari \\ Della Maghfira Napu
}

Manajemen Pemasaran Pariwisata, FPIPS UPI

\begin{abstract}
Davina Tour and Travel is one of the travel agents in Gorontalo city which has over four years of experience, serving a variety of business market share in tour \& travel. From year to year the number of domestic airline ticket purchase is increasing. Every year the Tour and Travel Davina always target purchase amount must be heightened, but in the year 2013 to 2014 has decreased the number of domestic airline ticket purchases. Decreasing the amount of the airline ticket purchase in 2014 due to the wishes and needs of its customers and the fierce competition among travel agents in the city of Gorontalo, Davina Tour and Travel doing word of mouth (word of mouth promotion) as effort to increase the number of ticket purchase domestic airlines. This research aims to reveal the word of mouth and purchasing decisions as well as word of mouth influence on purchasing decisions. This type of this research using descriptive and verification, used explanatory survey method and cross sectional approach. Sample in this research were 100 respondents, travelers who purchase airline tickets for domestic flights in Davina Tour and Travel with the sampling technique used is simple random sampling. Data analysis technique used is multiple regression. The independent variable in this research is the word of mouth $(X)$ consisting of cognitive content $\left(X_{1}\right)$, richness of content $\left(X_{2}\right)$ and the strength of delivery $\left(X_{3}\right)$ while the dependent variable is the purchasing decision $(Y)$ which is composed of indicators product choice, brand choice, dealer choice, purchase timing, purchase amount and payment method. Tourist's responses to word of mouth in Davina Tour and Travel considered sufficient high. Richness of content dimension to obtain the highest value whiles the cognitive content dimension to obtain the lowest value. Tourist's responses on purchasing decisions in Davina Tour and Travel considered sufficient high. Indicators of brand choice to obtain the highest value and the number of purchase to obtain the lowest value. Based on SPSS 20.0 for Windows testing showed that simultaneous and partial effect between word of mouth and purchasing decisions. The advice for company is improving communication with the sender of the WOM message and expressed positive messages and attractive so as to generate interest message recipients to buy airline tickets for domestic flights in Davina Tour and Travel.
\end{abstract}

Keywords: Word of Mouth, Purchase Decision, Davina Tour and Travel

\section{PENDAHULUAN}

Gorontalo sebagai salah satu destinasi wisata di Indonesia memiliki potensi yang besar untuk dikunjungi oleh para wisatawan, baik mancanegara maupun nusantara. Hal ini disebabkan karena pengembangan pariwisata Gorontalo didukung oleh keberagaman budaya dan persona alam yang memikat dari tiap kota dan kabupatennya. Selain itu Gorontalo memiliki potensi dalam pengembangan industri jasa pariwisata terutama biro perjalanan wisata dan travel agent dapat dilihat dari pertumbuhannya yang cukup pesat. Rata-rata travel agent di Kota Gorontalo kegiatannya hanya berkonsentrasi pada penjualan tiket maskapai penerbangan. Salah satu usaha perjalanan wisata di kota Gorontalo adalah Davina Tour and Travel.

Davina Tour and Travel memiliki pengalaman selama hampir 4 tahun sebagai perusahaan jasa tour \& travel. Davina Tour and Travel melayani berbagai pangsa pasar dalam bisnis tour \& travel, mengutamakan kepuasan pelanggan dengan terus berusaha memberikan pelayanan yang terbaik, baik dalam segi manajemen maupun operasional. Produk dan jasa yang ditawarkan oleh Davina Tour and Travel adalah Airlines Ticketing yang menyediakan tiket maskapai penerbangan domestik dan akan melayani tiket maskapai penerbangan internasional dengan sistem reservasi online, menyediakan voucher hotel domestik dengan sistem reservasi online, melayani pembuatan dokumen perjalanan seperti passport, kitas, selain itu menawarkan paket Meeting-IncentivesConvention \& Exhibiton (MICE).

Mengingat tingkat persaingan terus meningkat, maka pihak perusahaan harus meningkatkan kinerja perusahaan salah satunya adalah kinerja pemasaran, untuk membangun hubungan jangka panjang dengan pelanggannya atau calon pelanggan lain. Promosi adalah salah satu unsur bauran pemasaran yang sangat strategis terhadap peningkatan volume penjualan. Berkaitan dengan pentingnya masalah pemasaran, maka hal ini perlu diperhatikan oleh perusahaan Davina Tour and Travel, yakni sebuah perusahaan yang bergerak dibidang penjualan tiket maskapai penerbangan, dimana dalam upaya untuk mengantisipasi 
persaingan yang semakin ketat dengan perusahaan jasa perjalanan lainnya, serta untuk lebih meningkatkan penjualan tiket maskapai penerbangan, maka perusahaan perlu melakukan evaluasi mengenai strategi pemasaran yang dilakukan oleh perusaahan. Untuk lebih jelasnya berikut ini akan disajikan data pembelian tiket maskapai penerbangan di Davina Tour and Travel dari tahun 2011-2014 yang dapat dilihat melalui tabel 1.3 berikut ini:

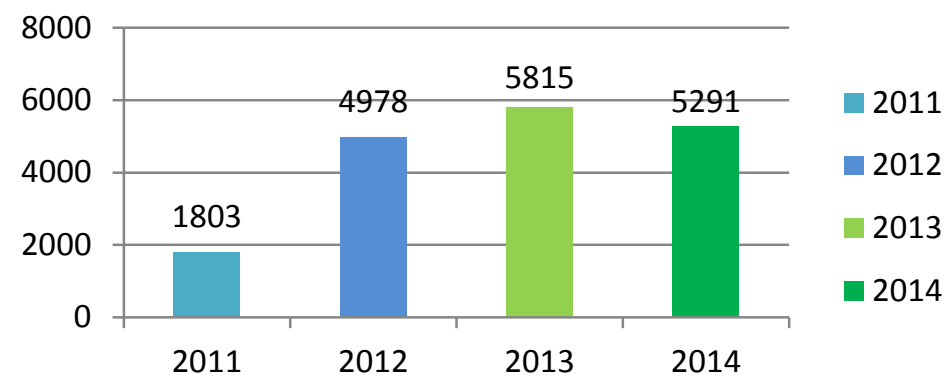

Sumber: Davina Tour and Travel, 2014

GRAFIK 1.1

JUMLAH PEMBELI TIKET MASKAPAI PENERBANGAN DOMESTIK TAHUN 2011-2014

Berdasarkan grafik 1.1 diatas, menunjukkan bahwa terjadi penurunan jumlah pembelian pada tahun 2014 dibandingkan pada tahun 2013 dimana terjadi kenaikan tingkat pembelian tiket maskapai penerbangan sebesar 5815, sedangkan pada tahun 2014 terjadi penurunan yang cukup drastis sebesar $9 \%$. Menurunnya jumlah pembelian tiket maskapai penerbangan pada tahun 2014 disebabkan oleh keinginan dan kebutuhan konsumen yang dinamis dan adanya persaingan ketat antar travel agent di Kota Gorontalo.

Perusahaan akan memperhatikan tingkat permintaan diimbangi dengan strategi yang digunakan oleh perusahaan. Konsumen yang pernah menggunakan jasa di Davina Tour and Travel akan menyarankan kepada keluarga, teman atau organisasi lainnya. Hal ini memberikan dampak positif bagi promosi Davina Tour and Travel secara tidak langsung.

Keterbatasan kemampuan promosi yang dilakukan oleh pihak Davina Tour and Travel menyebabkan Davina Tour and Travel mengandalkan alat promosi word of mouth untuk meningkatkan jumlah pembelian tiket maskapai penerbangan domestik. Word of mouth merupakan salah satu cara promosi yang tidak menggunakan media secara khusus dan sederhana namun berdampak sangat besar.

Lovelock (2011, hlm. 15) mengemukakan bahwa "Word of mouth sebagai pendapat dan rekomendasi yang dibuat oleh konsumen tentang pengalaman service, yang mempunyai pengaruh kuat terhadap keputusan konsumen atau perilaku pembelian". Berdasarkan permasalahan yang diuraikan, maka peneliti tertarik untuk melakukan penelitian dan menjadikan permasalahan yang terjadi sebagai topik penelitian dengan mengambil judul "Pengaruh Word of Mouth Terhadap Keputusan Pembelian Tiket Maskapai

\section{Penerbangan Domestik di Davina Tour and Travel Gorontalo".}

\subsection{Rumusan Masalah}

Dari latar belakang diatas, maka dapat dirumuskan masalah sebagai berikut.

1. Bagaimana gambaran word of mouth di Davina Tour and Travel Gorontalo.

2. Bagaimana gambaran keputusan pembelian tiket maskapai penerbangan domestik di Davina Tour and Travel Gorontalo.

3. Bagaimana pengaruh word of mouth yang terdiri dari cognitive content, richness of content, dan strength of delivery terhadap keputusan pembelian tiket maskapai penerbangan domestik di Davina Tour and Travel Gorontalo.

\subsection{Tujuan Penelitian}

Adapun tujuan dari penelitian ini adalah untuk mempelajari, mendeskripsikan, menganalisis dan menjelaskan hasil temuan tentang:

1. Word of mouth di Davina Tour and Travel Gorontalo.

2. Keputusan pembelian tiket maskapai penerbangan domestik di Davina Tour and Travel Gorontalo.

3. Bagaimana pengaruh word of mouth mouth yang terdiri dari cognitive content, richness of content, dan strength of delivery terhadap keputusan pembelian tiket maskapai penerbangan domestik di Davina Tour and Travel Gorontalo.

4.

\subsection{Kegunaan Penelitian}

Hasil yang diperoleh dari penelitian ini diharapkan dapat memberikan kegunaan: 


\section{Kegunaan Teoritis}

Penelitian ini diharapkan dapat menambah perluasan kajian ilmu mengenai pemasaran kepariwisataan dibidang jasa khususnya mengenai word of mouth terhadap keputusan pembelian tiket maskapai penerbangan domestik di Davina Tour and Travel Gorontalo. Kontribusi bagi pengembangan Ilmu Manajemen Pemasaran Pariwisata diharapkan dapat berguna bagi akademis dalam mengembangkan teori kepariwisataan.

\section{Kegunaan Praktis}

Penelitian ini dapat memberikan masukan kepada pihak Davina Tour and Travel Gorontalo mengenai word of mouth sebagai salah satu strategi yang paling efektif dan jangka panjang dalam menciptakan keputusan pembelian tiket maskapai penerbangan domestik di Davina Tour and Travel Gorontalo.

\section{KAJIAN PUSTAKA}

\subsection{Konsep Word of Mouth dalam}

\section{Manajemen Pemasaran}

Travel agent memiliki beberapa fungsi, menurut Yoeti (2006, hlm. 32-35) mengungkapkan travel agent memiliki dua fungsi yaitu sebagai perantara dan organisator, yaitu: Travel agent sebagai perantara yaitu menduduki tempat yang sangat penting dalam industri pariwisata, ia dapat dikatakan sebagai katalisator untuk membangun daerah-daerah baru sebagai daerah tujuan wisata. Karena itu peranannya dalam sektor ekonomi cukup berarti, terutama bagi daerah tujuan wisata yang sering dikunjungi oleh wisatawan. Travel agent sebagai organisator yaitu berfungsi mempersiapkan macam-macam tour yang mungkin dapat ditawarkan bagi calon wisatawan Taylor made sesuai dengan permintaan Ready made yang dapat dijual bebas pada orang banyak yang menghendakinya.

Menurut Kotler dan Keller (2012, hlm. 5) "Marketing management as the art and science of choosing target markets and getting, keeping, and growing customers through creating, delivering, and communicating superior customer value". Dapat diartikan bahwa manajemen pemasaran sebagai seni dan ilmu memilih pasar sasaran dan meraih, mempertahankan, serta menumbuhkan pelanggan dengan menciptakan, menghantarkan, dan mengkomunikasikan nilai pelanggan yang unggul.

Word of mouth, yaitu kegiatan pemasaran melalui perantara orang ke orang, tulisan ataupun alat komunikasi elektronik yang berhubungan dengan pengalaman pembelian jasa atau pengalaman menggunakan produk dan jasa. Penggunaan konsumen dari word of mouth untuk berbicara tentang puluhan merek setiap hari, dari media, dan produk hiburan seperti film, acara TV, dan publikasi untuk produk makanan, jasa perjalanan, dan toko ritel.

Dalam penelitian Jilian C. Sweeney, Geoffrey N. Soutar and Tim Mazzarol (2012: 240245) terdapat 3 dimensi WOM yang didasari oleh pemberi (sender) dan penerima (receiver) pesan , yaitu : (1) Cognitive content, yakni menggambarkan isi pesan sesuai dengan kinerja, respon terhadap masalah, dan persepsi, harga-nilai, sehingga mendukung gagasan bahwa WOM juga memiliki dimensi rasional. (2) Richness of content yakni kedalaman, intensitas, dan kejelasan dari pesan itu sendiri. Kekayaan meliputi aspek konten, seperti bahasa digunakan dan informasi yang terlibat dalam pesan. (3) Strength of delivery yakni kekuatan dari jalan pesan disampaikan. Ini berkaitan dengan cara dimana pesan tersebut disampaikan bukan dengan konten. Hal ini mencerminkan kekuatan niat rekomendasi.

\subsection{Keputusan Pembelian}

Kotler dan Keller (2012, hlm. 170) menyatakan bahwa dalam tahap evaluasi, konsumen membentuk preferensi diantara merek dalam kumpulan pilihan dan dapat membentuk niat untuk membeli merek yang paling disukai. Terdapat enam dimensi keputusan pembelian, yaitu: Product choice (Pemilihan produk), Brand choice (Pemilihan merek), Dealer choice (Pilihan penyalur), Purchase amount (Jumlah pembelian), Purchase timing (Waktu pembelian), dan Payment Method (Metode pembayaran). Ketiga hal tersebut merupakan dimensi dalam mengukur keputusan pembelian (Kotler dan Keller, 2012, hlm. 161).

\subsection{Paradigma Penelitian}

Paradigma penelitian yang merupakan cara pandang peneliti dalam melihat pengaruh word of mouth terhadap keputusan pembelian tiket maskapai penerbangan domestik pada gambar 2.1 dibawah ini.
Word of Mouth (Variabel X)

1. Cognitive content

2. Richness of content

3. Strength of
Keputusan Pembelian (Variabel Y)

1. Pemilihan Produk

2. Pemilihan Merek

3. Pilihan Penyalur

4. Waktu Pembelian

5. Jumlah Pembelian
Journal, Vol.VI No.1.2016- 1015 


\section{GAMBAR 2.1 \\ PARADIGMA PENELITIAN \\ PENGARUH WORD OF MOUTH TERHADAP KEPUTUSAN PEMBELIAN TIKET MASKAPAI PENERBANGAN DOMESTIK DI DAVINA TOUR AND TRAVEL GORONTALO}

\subsection{Hipotesis}

Berdasarkan pemaparan ini, maka peneliti mengemukakan hipotesis sebagai berikut:

"Terdapat pengaruh antara word of mouth terhadap keputusan pembelian tiket maskapai penerbangan domestik"

\section{METODE PENELITIAN}

\subsection{Objek Penelitian}

Penelitian ini menganalisis tentang pengaruh word of mouth terhadap keputusan pembelian. Objek penelitian yang menjadi variabel bebas (independent variable) adalah word of mouth (X) yang terdiri dari tiga dimensi yaitu cognitive content $\left(\mathrm{X}_{1}\right)$, richness of content $\left(\mathrm{X}_{2}\right)$ dan strength of delivery $\left(\mathrm{X}_{3}\right)$. Sedangkan yang menjadi variabel terikat (dependent variable) adalah keputusan pembelian (Y) memiliki indikator yaitu pilihan produk, pilihan merek, pilihan penyalur, waktu pembelian, jumlah pembelian dan metode pembayaran.

Unit analisis dalam penelitian ini adalah wisatawan yang membeli tiket maskapai penerbangan domestik di Davina Tour and Travel.

\subsection{Metode Penelitian}

Berdasarkan variabel-variabel yang diteliti maka metode penelitian yang dipergunakan adalah metode penelitian deskriptif dan verifikatif.

\subsection{Metode Penarikan Sampel}

Ukuran sampel dihitung dengan menggunaan rumus Slovin (Husein Umar, 2010:131). Berdasarkan rumus tersebut, dengan derajat kesalahan sebesar $10 \%$, maka jumlah responden yang dijadikan ukuran sampel dalam penelitian ini ialah sebanyak 100 responden.

\subsection{Teknik Pengumpulan Data}

Teknik pengumpulan data yang digunakan oleh penulis adalah sebagai berikut:

1. Angket (Kuesioner)

2. Wawancara

3. Studi Dokumentasi

4. Studi Literatur

\subsection{Pengujian Validitas dan Reliabilitas}

Selanjutnya, sebelum didistribusikan kepada responden, instrumen penelitian yang berupa kuesioner diuji terlebih dahulu. Uji yang dilakukan meliputi uji validitas dan reliabilitas. Hasil menunjukan bahwa instrumen penelitian valid dan reliabel.

\subsection{Pengujian Hipotesis}

Proses untuk menguji hipotesis dimana metode analisis yang dilakukan dalam penelitian ini adalah metode analisis verifikatif, maka dilakukan teknik analis regresi berganda (multiple regression). Analisis regresi berganda adalah hubungan secara linear antara dua atau lebih variabel independent $\left(\mathrm{X}_{1}, \mathrm{X}_{2}, \mathrm{X}_{3}\right)$ dengan variabel dependent (Y). Analisis ini untuk mengetahui arah hubungan antara variabel independent dengan variabel dependent apakah masing-masing variabel independent berhubungan positif atau negatif dan untuk memprediksi nilai dari variabel dependent apabila nilai variabel independent mengalami kenaikan atau penurunan. Data yang digunakan biasanya berskala interval atau rasio. Lebih jelasnya dapat dilihat pada gambar 3.1 berikut: 


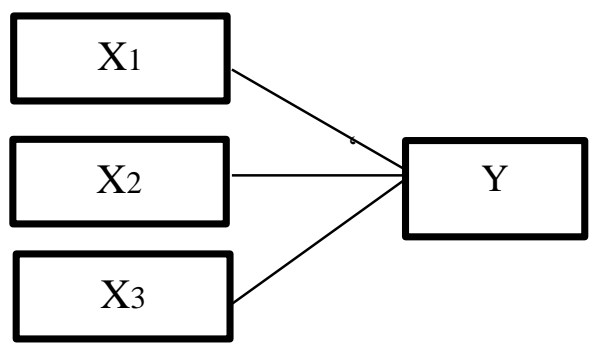

\section{GAMBAR 3.1 \\ REGRESI BERGANDA}

Kriteria pengambilan keputusan hipotesis secara statistik dalam rangka pengambilan keputusan penerimaan atau penolakan hipotesis dapat ditulis sebagai berikut:

\section{Secara Simultan}

A. $\mathrm{H}_{0}:$ bi $=0$ artinya tidak terdapat pengaruh yang signifikan antara word of mouth terhadap keputusan pembelian tiket maskapai penerbangan domestik di Davina Tour and Travel Gorontalo.

B. $\mathrm{H}_{1}$ : bi $\neq 0$ artinya terdapat pengaruh yang signifikan antara word of mouth terhadap keputusan pembelian tiket maskapai penerbangan domestik di Davina Tour and Travel Gorontalo.

\section{Secara Parsial}

A. $\mathrm{H}_{0}: \mathrm{b}_{1}=0$, artinya tidak terdapat pengaruh yang signifikan cognitive content terhadap keputusan pembelian

$\mathrm{H}_{1}: \mathrm{b}_{1} \neq 0$, artinya terdapat pengaruh yang signifikan cognitive content terhadap keputusan pembelian

B. $\mathrm{H}_{0}: \mathrm{b}_{2}=0$, artinya tidak terdapat pengaruh yang signifikan richness of content terhadap keputusan pembelian

$\mathrm{H}_{1}: \mathrm{b}_{2} \neq 0$, artinya terdapat pengaruh yang signifikan richness of content terhadap keputusan pembelian

C. $\mathrm{H}_{0}: \mathrm{b}_{3}=0$, artinya tidak terdapat pengaruh yang signifikan strength of delivery terhadap keputusan pembelian

$\mathrm{H}_{1}: \mathrm{b}_{3} \neq 0$, artinya terdapat pengaruh yang signifikan strength of delivery terhadap keputusan pembelian
IV. HASIL PENELITIAN DAN PEMBAHASAN

4.1 Hasil Tanggapan Responden Terhadap Word of Mouth di Davina Tour and Travel Gorontalo

TABEL 4.1

REKAPITULASI TANGGAPAN RESPONDEN TERHADAP WORD OF MOUTH DAVINA TOUR AND TRAVEL

\begin{tabular}{|c|c|c|c|c|}
\hline No & $\begin{array}{c}\text { Sub } \\
\text { Variabel }\end{array}$ & $\begin{array}{c}\text { Total } \\
\text { Skor }\end{array}$ & $\begin{array}{c}\text { Skor } \\
\text { Rata- } \\
\text { rata }\end{array}$ & $\%$ \\
\hline 1 & $\begin{array}{c}\text { Cognitive } \\
\text { Content }\end{array}$ & 1087 & 362,33 & 32,39 \\
\hline 2 & $\begin{array}{c}\text { Richness } \\
\text { of Content }\end{array}$ & 1514 & 378,5 & 33,84 \\
\hline 3 & $\begin{array}{c}\text { Strength of } \\
\text { Delivery }\end{array}$ & 1133 & 377,67 & 33,77 \\
\hline \multicolumn{2}{|c|}{ Total } & $\mathbf{3 7 3 4}$ & $\mathbf{1 1 1 8 , 5}$ & $\begin{array}{c}\mathbf{1 0 0} \\
\mathbf{\%}\end{array}$ \\
\hline
\end{tabular}

Sumber: Hasil Pengolahan Data, 2015

Tabel 4.1 menjelaskan bahwa dimensi yang mendapatkan penilaian paling tinggi adalah richness of content dengan persentase sebesar 33,84\% hal ini dikarenakan richness of content merupakan keluasan atau kelengkapan dari suatu isi pesan yang akan disampaikan dan kerincian informasi isi pesan dalam prosesnya sejauh mana pesan tersebut dapat mempengaruhi penerima pesan sehingga menimbulkan minat dan memperkuat kesan yang dimilikinya tentang produk dan jasa yang ditawarkan oleh Davina Tour and Travel.

Strength of delivery mendapatkan nilai sebesar 33,77\% hal ini dikarenakan strength of delivery merupakan kekuatan dalam penyampaian pesan yaitu dalam proses sejauh mana pesan suatu produk atau jasa memiliki karakteristik yang diinginkan, dibutuhkan, berguna atau melakukan fungsi yang sesuai. Berdasarkan hasil rekapitulasi variabel tersebut, bagaimana keluasan atau kelengkapan isi pesan merupakan point yang cukup 
penting dalam WOM. Proses kekuatan penyampaian pesan ini mempengaruhi WOM terhadap wisatawan yang membeli tiket maskapai penerbangan di Davina Tour and Travel. Jillian C. Sweeney, Geoffrey N. Soutar and Tim Mazzarol (2012, hlm 242), kekuatan dari alur pesan yang disampaikan ini berkaitan dengan cara dimana pesan tersebut disampaikan bukan dengan konten. Dimensi ini mencerminkan kekuatan advokasi, apakah implisit atau eksplisit.

Penilaian terendah adalah cognitive content sebesar 32,39\%. Hal ini dikarenakan isi pesan yang bersifat rasional sehingga pengirim pesan harus memberikan pemahaman kepada penerima pesan. Pesan yang disampaikan tentang produk dan jasa Davina Tour and Travel sulit untuk diukur karena perlu bukti nyata dimana sisi rasional mengenai isi pesan itu harus terbukti.

Melihat nilai total skor yaitu 3734 maka disimpulkan bahwa word of mouth di Davina Tour and Travel sudah termasuk kategori cukup tinggi. Nilai maksimum yaitu 5000 dan nilai minimum yaitu 1000. Kategori cukup tinggi berada pada rentang nilai 3000 sampai 4000.

\subsection{Hasil Tanggapan Wisatawan Terhadap Keputusan Pembelian}

TABEL 4.2

REKAPITULASI TANGGAPAN RESPONDEN TERHADAP KEPUTUSAN PEMBELIAN DAVINA TOUR AND TRAVEL GORONTALO

\begin{tabular}{|c|c|c|c|c|}
\hline No & Indikator & $\begin{array}{l}\text { Total } \\
\text { Skor }\end{array}$ & $\begin{array}{c}\text { Skor } \\
\text { Rata- } \\
\text { rata }\end{array}$ & $\%$ \\
\hline 1 & $\begin{array}{l}\text { Pemilihan } \\
\text { Produk }\end{array}$ & 767 & 383,5 & 17,08 \\
\hline 2 & $\begin{array}{l}\text { Pemilihan } \\
\text { Merek }\end{array}$ & 783 & 391,5 & 17,43 \\
\hline 3 & $\begin{array}{l}\text { Pilihan } \\
\text { Penyalur }\end{array}$ & 732 & 366 & 16,30 \\
\hline 4 & $\begin{array}{c}\text { Waktu } \\
\text { Pembelian }\end{array}$ & 1140 & 380 & 16,92 \\
\hline 5 & $\begin{array}{l}\text { Jumlah } \\
\text { Pembelian }\end{array}$ & 716 & 358 & 15,94 \\
\hline 6 & $\begin{array}{c}\text { Metode } \\
\text { Pembayaran }\end{array}$ & 733 & 366,5 & 16,32 \\
\hline
\end{tabular}

\begin{tabular}{|l|l|l|l|} 
Total & $\mathbf{4 8 7 1}$ & $\mathbf{2 2 4 5 , 5}$ & $\mathbf{1 0 0 \%}$ \\
\hline
\end{tabular}

Sumber : Hasil Pengolahan Data, 2015

Tabel 4.2 diatas memperlihatkan bahwa indikator pemilihan merek. memiliki presentase paling tinggi yaitu 17,43\%. Hal ini dikarenakan Responden memilih merek yang menjadi faktor utama dalam memutuskan untuk menggunakan produk dan jasa yang ditawarkan oleh Davina Tour and Travel. Menurut Kotler dan Keller (2012, hlm. 161) "Konsumen harus mengambil keputusan tentang merek mana yang akan dibeli. Setiap merek memiliki perbedaan-perbedaan tersendiri. Dalam hal ini perusahaan harus mengetahui bagaimana konsumen memilih sebuah merek yang terpercaya".

Frekuensi rekan kerja atau orang lain yang menyarankan membeli produk di Davina Tour and Travel, semakin banyak yang merekomendasikan tentang produk dan jasa yang ditawarkan oleh Davina Tour and Travel semakin banyak juga yang memutuskan untuk melakukan pembelian di Davina Tour and Travel. Selin itu pemilihan merek karena kepopuleran Davina Tour and Travel juga dapat memberikan pengaruh positif.

Jumlah pembelian memperoleh skor terendah yaitu 15,94\%, hal ini dikarenakan jumlah kapasitas masing-masing available seat sudah ditentukan atau dibatasi untuk setiap travel agent.

. Berdasarkan hasil pengolahan yang telah disajikan di atas, dapat dilihat bahwa skor total untuk keputusan pembelian adalah 4871. Penilaian ini menunjukkan keputusan pembelian berada pada kategori cukup tinggi.

\subsection{Pengaruh Word of Mouth Terhadap Keputusan Pembelian Tiket Maskapai Penerbangan Domestik Di Davina Tour and Travel Gorontalo}

\subsubsection{Pengujian Hipotesis dan Uji Signifikansi Secara Simultan (Uji F)}

Uji $F$ digunakan untuk mengetahui pengaruh keseluruhan variabel bebas terhadap variabel terikat. Uji $F$ dapat dilakukan dengan membandingkan $F_{\text {hitung }}$ dengan $F_{\text {tabel }}$ untuk menguji signifikansi dari analisis regresi. Berikut output ANOVA seperti yang ditunjukkan pada Tabel 4.3 berikut :

TABEL 4.3

OUTPUT ANOVA 


\begin{tabular}{|c|c|c|c|c|c|}
\hline \multicolumn{6}{|c|}{ ANOVA $^{a}$} \\
\hline Model & $\begin{array}{l}\text { Sum of } \\
\text { Squares }\end{array}$ & $\mathrm{df}$ & $\begin{array}{l}\text { Mean } \\
\text { Square }\end{array}$ & $\mathrm{F}$ & Sig. \\
\hline $\begin{array}{ll} & \text { Regression } \\
1 & \text { Residual } \\
& \text { Total }\end{array}$ & $\begin{array}{l}3449.068 \\
3891.234 \\
7340.302\end{array}$ & $\begin{array}{l}3 \\
96 \\
99\end{array}$ & $\begin{array}{l}1149.689 \\
40.534\end{array}$ & 28.364 & $.000^{\mathrm{b}}$ \\
\hline
\end{tabular}

a. Dependent Variable: Y

Sumber: Hasil Pengolahan Data Primer, 2015

Tabel 4.26 menunjukkan bahwa $F_{\text {hitung }}=28,364$ merupakan nilai $F_{\text {hitung }}$ dari korelasi antara setiap dimensi word of mouth (X) terhadap variabel keputusan pembelian secara simultan dengan tingkat probabilitas sig. 0,000. Nilai $F_{\text {hitung }}=28,364$, jika dibandingkan dengan Ftabel yaitu 3,94 maka Fhitung $>\mathrm{F}_{\text {tabel }}$ yang berarti bahwa setiap dimensi word of mouth (X) secara simultan memiliki pengaruh yang signifikan terhadap variabel keputusan pembelian. Oleh karena nilai signifikansi sebesar 0,000 lebih kecil dari 0,05 maka H0 ditolak dan $\mathrm{H}_{1}$ diterima. $\mathrm{H}_{1}$ : bi $\neq 0$ artinya terdapat pengaruh yang signifikan antara word of mouth di

TABEL 4.27

KOEFISIEN REGRESI

Coefficients $^{\mathrm{a}}$

\begin{tabular}{|c|c|c|c|c|c|c|c|c|}
\hline \multirow{2}{*}{\multicolumn{2}{|c|}{ Model }} & \multicolumn{2}{|c|}{$\begin{array}{l}\text { Unstandardized } \\
\text { Coefficients }\end{array}$} & \multirow{2}{*}{$\begin{array}{c}\begin{array}{c}\text { Standardized } \\
\text { Coefficients }\end{array} \\
\text { Beta }\end{array}$} & \multirow[t]{2}{*}{$\mathrm{t}$} & \multirow[t]{2}{*}{ Sig. } & \multicolumn{2}{|c|}{ Collinearity Statistics } \\
\hline & & $\mathrm{B}$ & Std. Error & & & & Tolerance & VIF \\
\hline \multirow{4}{*}{1} & (Constant) & 13.206 & 4.697 & & 2.811 & .006 & & \\
\hline & $\mathrm{X} 1$ & .411 & .295 & .106 & 1.393 & .167 & .951 & 1.051 \\
\hline & $\mathrm{X} 2$ & .909 & .298 & .302 & 3.049 & .003 & .564 & 1.773 \\
\hline & X3 & 1.640 & .371 & .429 & 4.416 & .000 & .586 & 1.707 \\
\hline
\end{tabular}

a. Dependent Variable: Y

Sumber: Hasil Pengolahan Data Primer, 2015

Tabel 4.27 menunjukkan pengaruh secara parsial antara variabel word of mouth terhadap keputusan pembelian.Untuk mengetahui $t_{\text {tabel }}$ dilakukan dengan melihat ttabel pada degree of freedom $(d f)$ dan $\alpha=10 \%$ dengan uji dua pihak menjadi $5 \%$. Dengan membandingkan nilai $t_{\text {hitung }}$ dengan $t_{\text {tabel }}$ maka dapat dijelaskan:

1. Tidak terdapat pengaruh yang signifikan antara dimensi cognitive content terhadap keputusan pembelian dengan nilai signifikansi $0,167>0,005$ dan $t_{\text {hitung }} 1,393<$ $\mathrm{t}_{\text {tabel }}$ 1,66055 sehingga $\mathrm{H} 0$ diterima dan $\mathrm{H} 1$ ditolak.

2. Terdapat pengaruh yang signifikan antara dimensi richness of content terhadap keputusan pembelian dengan nilai signifikansi $0,003<0,005$ dan $t_{\text {hitung }} 3,049>$ $\mathrm{t}_{\text {tabel }}$ 1,66055 sehingga $\mathrm{H} 0$ ditolak dan $\mathrm{H} 1$ diterima.

3. Terdapat pengaruh yang signifikan antara dimensi strength of delivery terhadap keputusan pembelian dengan nilai signifikansi $0,000<0,005$ dan $t_{\text {hitung }} 4,416>$
Davina Tour and Travel yang terdiri dari cognitive content, richness of content, dan strength of delivery, terhadap keputusan pembelian tiket maskapai penerbangan domestik di Davina Tour and Travel. 4.3.2 Pengujian Hipotesis dan Uji Signifikansi Secara Parsial (Uji t)

Uji $t$ berbeda dengan uji $F$, dimana uji $t$ digunakan untuk pengaruh masing-masing variabel bebas terhadap variabel terikat. Uji $\mathrm{t}$ ini dapat dilakukan dengan membandingkan thitung dengan $t_{\text {tabel }}$. Berikut output koefisien regresi seperti yang ditunjukkan pada Tabel 4.27 berikut: 
wisatawan beranggapan bahwa pengetahuan mengenai produk dan jasa yang ditawarkan oleh davina tour and travel yang disampaikan oleh pengirim pesan kurang memberikan informasi secara jelas sehingga wisatawan kurang mempercayai pesan yang disampaikan.

\subsection{Model Persamaan Regresi Berganda}

Pengaruh Word of Mouth terhadap Keputusan Pembelian

Persamaan regresi berganda untuk pengaruh word of mouth terhadap keputusan pembelian tiket maskapai penerbangan domestik dapat dinyatakan sebagai berikut:

$$
\begin{aligned}
& \mathbf{Y}=\mathbf{a}+\mathbf{b}_{1} \mathbf{X}_{1}+\mathbf{b}_{2} \mathbf{X}_{2}+\mathbf{b}_{3} \mathbf{X}_{3} \\
& Y=13,206+0,411 X_{1}+0,909 X_{2}+1,640 X_{3} \\
& \text { Keterangan : } \\
& \mathrm{Y}=\text { Keputusan Pembelian } \\
& \mathrm{X}_{1} \quad=\text { Cognitive content } \\
& \mathrm{X}_{2} \quad=\text { Richness of content } \\
& \mathrm{X}_{3} \quad=\text { Strength of delivery }
\end{aligned}
$$

Hasil analisis menunjukkan nilai konstanta 13,206 artinya jika $\mathrm{X}_{1}, \mathrm{X}_{2}, \mathrm{X}_{3}$ diabaikan maka tingkat keputusan pembelian adalah sebesar 13,206. Koefisien $\mathrm{X}_{1}$ sebesar 0,411 berarti bahwa untuk setiap kenaikan satu satuan nilai cognitive content akan menaikkan nilai keputusan pembelian sebesar 0,411. Koefisien $\mathrm{X}_{2}$ sebesar 0,909 menyatakan bahwa untuk setiap kenaikan satu satuan nilai richness of content maka akan menaikkan nilai keputusan pembelian sebesar 0,909. Sedangkan koefisien $\mathrm{X}_{3}$ sebesar 1,640 yang berarti bahwa untuk setiap kenaikan satu satuan nilai strength of delivery maka akan menaikkan nilai keputusan pembelian sebesar 1,640.

\subsection{Implikasi Hasil Temuan Penelitian 4.5.1 Temuan Penelitian Bersifat Teoritik} Berdasarkan hasil kajian serta penelitian mengenai pengaruh word of mouth terhadap keputusan pembelian, maka dihasilkan temuan-temuan teoritis sebagai berikut:

1. Berdasarkan hasil temuan penelitian, penulis memperkuat teori dari Jillian C. Sweeney Geoffrey N. Soutar Tim Mazzarol, (2012, hlm. 250-251) yang menyatakan bahwa "Three WOM dimensions seem to underlie giving and receiving WOM messages. This finding matches the relationships identified in the giver context, in which the association of WOM with perceived service and value were not as strong for negative WOM. Valence seems to act as a moderator of the effect service quality and value perceptions have on WOM message content and delivery (giver context), as well as the effect WOM message content and delivery have on receivers' changes in perceptions of service quality and value".

2. Berdasarkan hasil temuan penelitian, penulis memperkuat teori yang dikemukakan oleh Kotler \& Keller (2012, hlm. 500) yang menyatakan bahwa "word of mouth marketing adalah komunikasi dari orang ke orang secara lisan, tertulis, atau elektronik yang berhubungan dengan manfaat dan pengalaman membeli atau menggunakan barang dan jasa”.

3. Berdasarkan hasil temuan penelitian, penulis memperkuat premis dari beberapa ahli yang menyatakan bahwa adanya hubungan antara word of mouth terhadap keputusan pembelian yaitu Nawaz A, Jolita V, dan Rizwan R. (2014, hlm.394) "In conclusion it is revealed that for purchasing mostly consumer trust on word of mouth. The respondents seem like to have an impact on consumers' decision and close family, close friend, and other associates. This is real fact that bad impression of any product/service can be created by once bad experience, which proved that negative word of mouth could have undesirable effects, but positive word of mouth could create a magical impression or image of products/services".

\subsubsection{Temuan Penelitian Bersifat Empirik}

Berdasarkan hasil penelitian mengenai pengaruh word of mouth terhadap keputusan pembelian, maka dihasilkan temuan-temuan empiris sebagai berikut:

1. Berdasarkan temuan penelitian penulis, menunjukkan bahwa word of mouth yang terdiri dari cognitive content, richness of content, dan strength of delivery secara simultan memiliki pengaruh yang signifikan terhadap keputusan pembelian tiket maskapai penerbangan domestik di Davina Tour and Travel. Namun secara parsial cognitive content tidak memiliki pengaruh secara signifikan. Tanggapan richness of content memiliki penilaian yang tinggi dari wisatawan, dimana keluasan dan kekayaan berada pada pesan yang disampaikan kepada pihak penerima pesan yang artinya bahwa word of mouth memiliki pengaruh yang signifikan terhadap keputusan pembelian.

2. Hasil dari keputusan pembelian di Davina Tour and Travel meliputi produk, pemilihan merek, pilihan penyalur, waktu pembelian, jumlah pembelian, dan metode pembayaran mendapat tanggapan cukup tinggi dari wisatawan. Nilai yang paling tinggi yaitu pemilihan merek dimana para wisatawan sebagian besar sering mendapatkan rekomendasi dari rekan kerja atau orang lain untuk menggunakan produk dan jasa yang ditawarkan oleh Davina Tour and Travel, selain itu nama Davina Tour and Travel popular dilingkungan masyarakat Gorontalo.

3. Berdasarkan hasil temuan penelitian ini maka diyakini bahwa hasil penelitian ini mengukuhkan teori sebelumnya word of mouth memberikan pengaruh terhadap 
keputusan pembelian pada wisatawan yang membeli tiket maskapai penerbangan di Davina Tour and Travel dan memperjelas bahwa word of mouth efektif bagi suatu agen perjalanan wisata.

Berdasarkan hasil temuan teoritik dan empirik, maka penelitian ini diyakini mampu memberikan sumbangan ilmiah bagi pengembangan ilmu manajemen pemasaran pariwisata khususnya mengenai word of mouth di Davina Tour and Travel.

\section{KESIMPULAN DAN REKOMENDASI}

\subsection{Kesimpulan}

Berdasarkan hasil penelitian yang telah dilakukan penelitian tersebut dapat diambil kesimpulan sebagai berikut:

1. Berdasarkan hasil tanggapan responden mengenai pelaksanaan word of mouth di Davina Tour and Travel yang terdiri dari 3 dimensi yaitu cognitive content, richness of content, dan strength of delivery dinilai cukup tinggi. Dimensi richness of content merupakan dimensi yang mendapatkan penilaian paling tinggi dari pelanggan Davina Tour and Travel . Dimana keluasan dan kekayaan berada pada pesan yang disampaikan oleh pihak pengirim pesan kepada pihak penerima pesan yang artinya bahwa word of mouth memiliki pengaruh yang signifikan terhadap keputusan pembelian. Dimensi cognitive content memperoleh skor terendah dikarenakan dimensi ini memiliki pengaruh yang sedikit atau tidak signifikan karena pihak penerima pesan beranggapan bahwa pengetahuan mengenai produk dan jasa yang ditawarkan oleh davina tour and travel yang disampaikan oleh pihak pengirim pesan kurang memberikan informasi secara jelas sehingga pihak penerima pesan kurang mempercayai pesan yang disampaikan. Davina Tour and Travel.

2. Tanggapan responden mengenai keputusan pembelian yang terdiri dari pemilihan produk, pemilihan merek, pilihan penyalur, waktu pembelian jumlah pembelian dan metode pembayaran dinilai cukup tinggi. Penilaian tertinggi ada pada pemilihan merek, dimana para wisatawan sebagian besar sering mendapatkan rekomendasi dari rekan kerja atau orang lain untuk menggunakan produk dan jasa yang ditawarkan oleh Davina Tour and Travel, selain itu nama Davina Tour and Travel popular dilingkungan masyarakat Gorontalo.

3. Berdasarkan pengujian hipotesis menunjukan word of mouth yang terdiri dimensi yaitu cognitive content, richness of content, dan strength of delivery secara simultan memiliki pengaruh yang signifikan terhadap keputusan pembelian tiket maskapai penerbangan domestik di Davina Tour and Travel Gorontalo. Namun secara parsial, cognitive content tidak berpengaruh secara signifikan.

\subsection{Rekomendasi}

Berdasarkan hasil penelitian yang telah dilakukan, maka penulis menyarankan beberapa hal mengenai pengaruh word of mouth keputusan pembelian tiket maskapai penerbangan domestik di Davina Tour and Travel Gorontalo, yaitu :

1. Word of mouth yang meliputi cognitive content, richness of content, dan strength of delivery secara keseluruhan berpengaruh terhadap keputusan pembelian tiket maskapai penerbangan domestik. WOM merupakan kegiatan yang tidak dapat dikendalikan oleh organisasi/perusahaan.

2. Keputusan pembelian tiket maskapai penerbangan domestik di Davina Tour and Travel cukup tinggi. Keputusan pembelian terendah yakni berada pada jumlah pembelian. Hal ini dikarenakan jumlah kapasitas masingmasing available seat sudah ditentukan atau dibatasi untuk setiap travel agent. Selain itu dikarenakan oleh faktor utama yaitu keterbatasan jumlah maskapai penerbangan yang beroperasi di Provinsi Gorontalo.

3. Pelaksanaan word of mouth yang diterapkan di Davina Tour and Travel mendapatkan penilaian yang cukup tinggi oleh wisatawan individu yang membeli tiket maskapai penerbangan domestik. Maka dari itu, seluruh karyawan diharapkan selalu menjaga Standard Operational Procedure (SOP) dan prinsip-prinsip pelayanan yang telah ditetapkan oleh Davina Tour and Travel. Disamping itu dalam rangka meningkatkan keputusan pembelian tiket maskapai penerbangan domestik, harus diimbangi dengan pesan-pesan yang positif dan menarik yang akan disampaikan ketika proses word of mouth itu terjadi.

4. Setiap penelitian tentunya memiliki kekurangan dan keterbatasan, begitu juga dengan penelitian ini yang memiliki kekurangan dan keterbatasan karena hanya dilakukan pada pelanggan individu dan keputusan pembelian di Davina Tour and Travel Gorontalo.

\section{DAFTAR PUSTAKA}

Arikunto, S. (2009). Prosedur Penelitian: Suatu Pendekatan Praktik. Jakarta: Rineka Cipta (2013). Prosedur Penelitian: Suatu Pendekatan Praktik. Jakarta: Rineka Cipta Davina Tour and Travel Ticketing Issued Report 
Kotler, Philip \& Keller. (2012). Marketing Management, $14^{\text {th }}$ Edition. New Jersey: Prentice Hall

Lovelock, Christopher and Wirtz, Jochen. (2011). Marketing Management; Customer behavior 7th Edition. Pearson Edication; Boston

Nawaz A, Jolita V, dan Rizwan R. (2014). Impact of Word of Mouth on Consumer Buying Decision. 394-403

Sweeney, Jillian C., Geoffrey N. Soutar and Tim Mazzarol. (2012). Word of Mouth: Measuring The Power of Individual Message. European Journal of Marketing, 46 (1/2), hlm. 237-257

Umar, Husein. (2010). Metode Penelitian Untuk Skripsi dan Tesis Bisnis. Jakarta: Rajagrafindo Persada

Yoeti, Oka A. (2006). Tours and Travel Marketing. Jakarta: PT. Pradnya Paramita 